\title{
TINDAKAN MASYARAKAT TEHADAP PENYAKIT MALARIA DI KECAMATAN SILIAN RAYA KABUPATEN MINAHASA TENGGARA
}

\author{
${ }^{1}$ Regina C. Tawas \\ ${ }^{2}$ Victor D. Pijoh \\ ${ }^{2}$ Josef S. B. Tuda \\ ${ }^{1}$ Kandidat Skripsi Fakultas Kedokteran Universitas Sam Ratulangi Manado \\ ${ }^{2}$ Bagian Parasitologi Fakultas Kedokteran Universitas Sam Ratulangi \\ Email: rtawas_11_058@yahoo.com
}

\begin{abstract}
Malaria is a tropical disease caused by parasites of the genus Plasmodium, protozoa which belonged mediated through the bite of Anopheles spp. Based on the World Malaria Report 2012, recorded 219 million cases of malaria in the world with 660,000 deaths that occurred in 2010 and Indonesia is one of 104 countries including malaria endemic countries. The purpose of this study was to determine the public action against malaria in Silian Raya Sub district Southeast Minahasa Regency. This research uses descriptive survey research by interviews using questionnaires and observation. The population is the entire population in Southeast Silian Raya Sub district Southeast Minahasa Regency that there are 5731 residents and 194 samples obtained by existing residents. Sampling studies using cluster random sampling system based on the population of each village as a cluster. The sampling technique for each environment using simple random sampling technique.The results obtained are the actions of the respondents against malaria among others habits are outside the house at night for $90.2 \%$, ownership of mosquito nets $85.6 \%$, custom clothes hanging in the home by $93.3 \%$, in the habit of using drug mosquito that only $24.7 \%$, habits in the use of repellent or Autan by $1.5 \%$, and the use of wire mesh ventilation of $4.6 \%$.
\end{abstract}

Keywords: malaria, community action.

\begin{abstract}
Abstrak: Penyakit malaria merupakan penyakit tropis yang disebabkan oleh parasit genus Plasmodium, yang termasuk golongan protozoa melalui perantaraan gigitan nyamuk Anopheles spp. Berdasarkan The World Malaria Report 2012, tercatat 219 juta kasus malaria dengan 660.000 kematian di dunia yang terjadi pada tahun 2010 dan Indonesia merupakan salah satu dari 104 negara yang termasuk negara endemis malaria. Tujuan penelitian ini adalah untuk mengetahui tindakan masyarakat terhadap penyakit malaria di Kecamatan Silian Raya Kabupaten Minahasa Tenggara. Penelitian ini menggunakan jenis penelitian survey yang bersifat deskriptif dengan melakukan wawancara menggunakan kuesioner dan observasi. Populasi adalah seluruh penduduk di Kecamatan Silian Raya Kabupaten Minahasa Tenggara yaitu ada 5731 penduduk dan sampel yang diperoleh ada 194 penduduk. Pengambilan sampel penelitian menggunakan sistem Cluster Random Sampling berdasarkan penduduk pada masing-masing desa sebagai cluster. Teknik pengambilan sampel untuk setiap lingkungan menggunakan teknik Simple Random Sampling. Hasil penelitian yang didapat yaitu tindakan responden terhadap penyakit malaria antara lain kebiasaan berada diluar rumah pada malam hari sebesar 90,2\%, kepemilikan kelambu 85,6\%, kebiasaan menggantung pakaian didalam rumah sebesar 93,3\%, kebiasaan dalam menggunakan obat nyamuk yang hanya $24,7 \%$, kebiasaan dalam penggunaan repelen atau autan sebesar $1,5 \%$, dan penggunaan kawat kasa ventilasi sebesar $4,6 \%$.
\end{abstract}

Kata kunci: malaria, tindakan masyarakat. 
Malaria termasuk salah satu dari penyakit menular yang upaya pengendaliannya menjadi komitmen global dalam Millenium Development Goal (MDG'S) yang dideklarasikan oleh 189 negara anggota Persatuan Bangsa-Bangsa (PBB) pada tahun 2000. Sampai saat ini malaria masih menjadi masalah global karena selain menyerang penduduk usia produktif juga banyak menyebabkan kematian pada bayi, anak balita serta wanita. ${ }^{1}$ Data World Health Organisation (WHO) mencatat setiap tahunnya tidak kurang dari 1 hingga 2 juta penduduk meninggal karena penyakit yang disebarluaskan oleh nyamuk Anopheles spp. Sebanyak 270 juta penduduk dunia menderita malaria dan lebih dari 2 miliar atau 42\% penduduk dunia memiliki risiko terkena malaria. ${ }^{2}$

Berdasarkan The World Malaria Report 2012, tercatat 219 juta kasus malaria dengan 660.000 kematian di dunia yang terjadi pada tahun 2010 dan Indonesia merupakan salah satu dari 104 negara yang termasuk negara endemis malaria. ${ }^{3} \mathrm{Di}$ Indonesia menurut WHO pada tahun 2006, lebih dari 90 juta penduduk tinggal di daerah endemis dengan kasus sekitar 30 juta setiap tahun. Pada tahun 2010 diperkirakan $60 \%$ penduduk tinggal di daerah endemis malaria yang tingkat endemisitasnya beragam. Di Jawa dan Bali insiden malaria pada tahun 2000 adalah 81 per 100.000 penduduk, daerah selain Bali dan Jawa insiden malaria klinis pada tahun 2000 jauh lebih banyak yaitu 31 per 1.000 penduduk dan angka kematian spesifik akibat malaria sebesar 11 per 100.000 untuk laki-laki dan 8 per 100.000 untuk perempuan. $^{4}$

Tahun 2010 jumlah kasus malaria yang ada di Provinsi Sulawesi Utara mengalami peningkatan, dari Annual Parasite Incidence (API) sebesar 1,63 per 1000 penduduk naik menjadi 2,52 per 1000 penduduk pada tahun 2011. Kabupaten Minahasa Tenggara merupakan salah satu Kabupaten/Kota dengan jumlah kasus malaria yang tinggi, di mana pada tahun 2011 kasus malaria positif adalah 2001 kasus dan terjadi peningkatan kasus pada tahun 2012 menjadi 2005 positif malaria. ${ }^{5}$ Berdasarkan data dari Laporan Bulanan Kasus Malaria di Puskemas Kecamatan Silian Raya pada bulan Januari sampai Oktober 2014 di dapat setiap bulannya ada penduduk yang menderita malaria. Pada bulan Januari sampai Oktober 2014 ada 752 penduduk yang datang ke puskesmas dengan gejala malaria dan didapat ada 159 penduduk yang positif malaria. ${ }^{6}$

Kecamatan Silian Raya merupakan kecamatan yang masih baru karena merupakan hasil pemekaran dari kecamatan Toluaan. Sebagian besar penduduk bermata pencaharian sebagai petani. Kondisi geografis yang ada menjadi salah satu faktor berkembangnya penyakit malaria. ${ }^{7}$ Keadaan timbul dan hilangnya suatu penyakit dipengaruhi oleh aspek sosial budaya masyarakat setempat, salah satu diantaranya adalah perilaku. ${ }^{8}$ Untuk terbentuknya perilaku individu yang baik, maka individu tersebut harus mempunyai pengetahuan yang baik, sikap positif dan tindakan yang baik. Faktor-faktor yang mempengaruhi tindakan sangat berkaitan dengan keseluruhan pemahaman dan aktivitas seseorang yang merupakan hasil bersama antara faktor internal dan faktor eksternal. Faktor internal yaitu karakteristik dalam diri seseorang yakni umur, jenis kelamin, pekerjaan serta pendidikan. Faktor eksternal yakni lingkungan, baik lingkungan fisik, sosial, ekonomi, budaya serta informasi kesehatan. ${ }^{9}$ Masalah penyakit malaria ini bukan saja di pengaruhi oleh faktor lingkungan dan pelayanan kesehatan tetapi juga dipengaruhi oleh faktor perilaku dimana didalamnya ada aspek tindakan. Tindakan yang tidak waspada terhadap penyakit malaria merupakan pendukung hadirnya vektor malaria. ${ }^{10}$

Tujuan penelitian ini adalah untuk mengetahui tindakan masyarakat terhadap penyakit malaria di Kecamatan Silian Raya Kabupaten Minahasa Tenggara.

\section{METODE PENELITIAN}

Jenis penelitian adalah survey yang bersifat deskriptif, untuk mengetahui 
tindakan masyarakat terhadap penyakit malaria. Populasi dalam penelitian ini adalah penduduk yang berada di Kecamatan Silian Raya Kabupaten Minahasa Tenggara. Sampel yang diperoleh adalah 194 penduduk. Pengambilan sampel penelitian menggunakan sistem Cluster Random Sampling berdasarkan penduduk pada masing-masing desa sebagai cluster. Teknik pengambilan sampel untuk setiap lingkungan menggunakan teknik Simple Random Sampling. Metode dan pengumpulan data yaitu data primer (wawancara dan observasi) dan data sekunder (literature yang relevan dengan penelitian). Data yang diperoleh dibuat dalam sistem tabulasi menggunakan aplikasi soft ware SPSS 20, kemudian diuraikan dalam bentuk narasi.

\section{HASIL PENELITIAN}

\section{Gambaran umum Kecamatan Silian Raya}

Kecamatan Silian Raya terdapat 10 desa, dengan luas wilayah 4038,86 Нa. Berdasarkan data laporan kependudukan kecamatan Silian Raya pada September 2014 didapat 1624 kepala keluarga dengan jumlah penduduk 5731. Laki-laki sebanyak 2956 dan perempuan sebanyak 2775.

Karakteristik responden meliputi: umur, jenis kelamin, pendidikan dan pekerjaan. Secara garis besar karakteristik responden di kecamatan Silian Raya pada tahun 2014 dapat dilihat pada dibawah ini:

Tabel 1. Karakteristik responden menurut usia

\begin{tabular}{lccc}
\hline & Umur & Jumlah & Persen (\%) \\
\hline 1. & $15-20$ & 6 & 3,1 \\
2. & $20-30$ & 41 & 21,1 \\
3. & $30-40$ & 41 & 21,1 \\
4. & $40-50$ & 54 & 27,8 \\
5. & $50-60$ & 39 & 20,1 \\
6. & $>60$ & 13 & 6,7 \\
\hline & Jumlah & 194 & 100 \\
\hline
\end{tabular}

Berdasarkan Tabel 1, sebagian besar responden berumur antara 40-50 tahun yaitu $27,8 \%$ dan paling sedikit berumur 15-20 tahun 3,1\%.

Tabel 2. Karakteristik responden menurut jenis kelamin

\begin{tabular}{llcc}
\hline & Jenis Kelamin & Jumlah & Persen (\%) \\
\hline 1. & Laki-laki & 73 & 37,6 \\
2. & Perempuan & 121 & 62,4 \\
\hline & Jumlah & 194 & 100 \\
\hline
\end{tabular}

Berdasarkan Tabel 2, sebagian besar responden adalah perempuan yaitu $62,4 \%$ sedangkan laki-laki 37,6\%.

Tabel 3. Karakteristik responden menurut pekerjaan

\begin{tabular}{llcc}
\hline & Pekerjaan & Jumlah & $\begin{array}{c}\text { Persen } \\
(\%)\end{array}$ \\
\hline 1. & PNS/TNI/POLRI & 12 & 6,2 \\
2. & Pegawai Swasta & 1 & 0,55 \\
3. & Pedagang & 3 & 1,5 \\
4. & Nelayan & 1 & 0,55 \\
5. & Petani/ Berkebun & 72 & 37,1 \\
6. & IRT & 100 & 51,5 \\
7. & Wiraswasta & 5 & 2,6 \\
\hline & Jumlah & 194 & 100 \\
\hline
\end{tabular}

Berdasarkan Tabel 3, sebagian besar responden memiliki pekerjaan sebagai IRT yaitu 54,1\%.

Tabel 4. Karakteristik responden menurut pendidikan

\begin{tabular}{llcc}
\hline & Pendidikan & Jumlah & $\begin{array}{c}\text { Persen } \\
(\%)\end{array}$ \\
\hline 1. & Tidak sekolah/ tidak & - & - \\
& tamat SD & & \\
2. & Tamat SD & 34 & 17,5 \\
3. & Tamat SMP & 98 & 50,5 \\
4. & Tamat SMA & 50 & 25,8 \\
5. & Tamat Perguruan & 12 & 6,2 \\
& Tinggi (DIII, S1, S2) & & \\
\hline & Jumlah & 194 & 100 \\
\hline
\end{tabular}

Berdasarkan Tabel 4, sebagian besar responden berpendidikan SMP yaitu 50,5\%. 
Tawas, Pijoh, Tuda: Tindakan masyarakat terhadap...

\section{Tindakan}

Berdasarkan hasil penelitian terhadap masyarakat di kecamatan Silian Raya dan lebih khusus pada 194 responden yang sudah mengisi kuesioner penelitian ini, maka diperoleh tabel-tabel yang menggambarkan perilaku masyarakat terhadap penyakit malaria itu sendri, seperti di bawah ini:

Tabel 5. Distribusi responden berdasarkan sering berada di luar rumah pada malam hari \& aktivitas di luar rumah pada malam hari

\begin{tabular}{ccc}
\hline $\begin{array}{l}\text { Sering berada di luar } \\
\text { rumah waktu malam hari }\end{array}$ & $\begin{array}{c}\text { Persen } \\
\text { (\%) }\end{array}$ \\
\hline \multicolumn{1}{c}{ a. Ya } & 175 & 90,2 \\
b. Tidak & 19 & 9,8 \\
\hline Jumlah & 194 & 100 \\
\hline Aktivitas di luar rumah & & \\
\hline \multicolumn{1}{l}{ a. $\begin{array}{l}\text { Santai dengan } \\
\quad \text { tetangga/teman }\end{array}$} & 40 & 22,9 \\
b. Pertemuan \\
$\quad \begin{array}{l}\text { masyarakat/ibada } \\
\text { h kolom }\end{array}$ & 135 & 77,1 \\
\hline Jumlah & 175 & 100 \\
\hline
\end{tabular}

Berdasarkan Tabel 5 di atas 90,2\% sering berada di luar rumah pada malam hari dan 9,8\% yang tidak sering berada di luar rumah pada malam hari. Dan untuk aktivitas di luar rumah 22,9\% responden memilih santai dengan tetangga/teman dan $77,1 \%$ memilih pertemuan masyarakat/ ibadah kolom sebagai aktivitas di luar rumah pada malam hari.

Tabel 6. Distribusi responden berdasarkan jam sudah tidak berada di luar rumah (tidur) pada malam hari

\begin{tabular}{clcc}
\hline $\begin{array}{l}\text { Jam } \\
\text { berada diluar rumah }\end{array}$ & $\begin{array}{c}\text { berapa tidak } \\
\text { a. Jam 8 malam }\end{array}$ & $\begin{array}{c}\text { Persen } \\
(\%)\end{array}$ \\
\hline b. Jam 9 malam & 71 & 42,8 \\
c. Jam 10 malam & 21 & 36,5 \\
d. & jam 11 & - & - \\
e. & Lain-lain & 19 & 9,8 \\
\hline & Jumlah & 194 & 100 \\
\hline
\end{tabular}

Berdasarkan Tabel 6 paling banyak yaitu 42,8\% memilih jam 8 sudah tidak berada diluar rumah pada malam hari.

Tabel 7. Distribusi responden berdasarkan kebiasaan tidur

\begin{tabular}{|c|c|c|}
\hline $\begin{array}{l}\text { Lebih senang tidur } \\
\text { dimana }\end{array}$ & Jumlah & $\begin{array}{c}\text { Persen } \\
(\%)\end{array}$ \\
\hline a. Kamar & 192 & 99 \\
\hline b. Ruang Tamu & 2 & 1 \\
\hline $\begin{array}{l}\text { c. Luar/Teras } \\
\text { rumah }\end{array}$ & - & - \\
\hline Jumlah & 194 & 100 \\
\hline
\end{tabular}

Berdasarkan Tabel 7 di atas 99\% memilih kamar dan 1\% memilih ruang tamu sebagai temtpat dimana senang tidur.

Tabel 8. Distribusi responden berdasarkan kepemilikan kelambu

\begin{tabular}{|c|c|c|}
\hline $\begin{array}{l}\text { Kepemilikan } \\
\text { kelambu }\end{array}$ & Jumlah & Persen (\%) \\
\hline $\begin{array}{ll}\text { a. } & \text { Ya } \\
\end{array}$ & 166 & 85,6 \\
\hline b. Tidak & 28 & 14,4 \\
\hline Jumlah & 194 & 100 \\
\hline
\end{tabular}

Berdasarkan Tabel $\quad 8, \quad 85,6 \%$ responden memiliki kelambu dan 14,4\% responden tidak memiliki kelambu.

Tabel 9. Distribusi responden berdasarkan kebiasaan menggantung pakaian di dalam rumah

\begin{tabular}{|c|c|c|}
\hline $\begin{array}{l}\text { Kebiasaan } \\
\text { menggantung pakaian } \\
\text { di dalam rumah }\end{array}$ & Jumlah & $\begin{array}{c}\text { Persen } \\
\text { (\%) }\end{array}$ \\
\hline a. Ya & 181 & 93,3 \\
\hline b. Tidak & 13 & 6,7 \\
\hline Jumlah & 194 & 100 \\
\hline
\end{tabular}

Berdasarkan Tabel 9, 93,3\% memilih ya dan $6,7 \%$ memilih tidak dalam kebiasaan menggantung pakaian di dalam rumah.

Berdasarkan Tabel 10, 57,7\% memilih kadang-kadang, $24,7 \%$ memilih ya dan $17,5 \%$ memilih tidak dalam menggunakan obat pembasmi nyamuk pada malam hari.

Berdasarkan Tabel 11, 88,1\% memilih tidak, $10.3 \%$ memilih kadang-kadang, dan $1,5 \%$ memilih ya dalam menggunakan repelen pada malam hari. 
Tabel 10. Distribusi responden berdasarkan penggunaan obat pembasmi nyamuk malam hari

\begin{tabular}{|c|c|c|}
\hline $\begin{array}{l}\text { Menggunakan obat } \\
\text { pembasmi nyamuk } \\
\text { setiap malam }\end{array}$ & Jumlah & $\begin{array}{c}\text { Persen } \\
\text { (\%) }\end{array}$ \\
\hline a. $\mathrm{Ya}$ & 48 & 24,7 \\
\hline $\begin{array}{ll}\text { b. } & \text { Kadang- } \\
\text { kadang }\end{array}$ & 112 & 57,7 \\
\hline c. Tidak & 34 & 17,5 \\
\hline Jumlah & 194 & 100 \\
\hline
\end{tabular}

Tabel 11. Distribusi responden berdasarkan penggunaan repelen malam hari

\begin{tabular}{|c|c|c|}
\hline $\begin{array}{l}\text { Menggunakan } \\
\text { repelen pada malam } \\
\text { hari }\end{array}$ & Jumlah & $\begin{array}{c}\text { Persen } \\
(\%)\end{array}$ \\
\hline a. Ya & 3 & 1,5 \\
\hline $\begin{array}{l}\text { b. Kadang- } \\
\text { kadang }\end{array}$ & 20 & 10,3 \\
\hline c. Tidak & 171 & 88,1 \\
\hline Jumlah & 194 & 100 \\
\hline
\end{tabular}

Tabel 12. Distribusi responden berdasarkan penggunaan kawat kasa ventilasi

\begin{tabular}{|c|c|c|}
\hline $\begin{array}{l}\text { Menggunakan } \\
\text { kawat kasa pada } \\
\text { ventilasi }\end{array}$ & Jumlah & $\begin{array}{c}\text { Persen } \\
\text { (\%) }\end{array}$ \\
\hline a. Ya & 9 & 4,6 \\
\hline b. Tidak & 185 & 95,4 \\
\hline Jumlah & 194 & 100 \\
\hline
\end{tabular}

Berdasarkan Tabel 12 di atas, 95,4\% memilih tidak, dan $4,6 \%$ memilih ya dalam penggunaan kawat kasa ventilasi.

Berdasarkan Tabel 13, 76,8\% memilih ya dan $23,2 \%$ memilih tidak dalam sering mendapat kunjungan tamu dan menginap dirumah. Dan 93,3\% mendapat kunjuang dari keluarga atau tamu dari luar Kabupaten Minahasa Tenggara, dan 6,7\% mendapat kunjuang dari keluarga atau tamu dari dalam Kabupaten Minahasa Tenggara.

Berdasarkan Tabel 14, 78,4\% memilih ya dan $21,6 \%$ memilih tidak dalam berpergian keluar daerah pada beberapa waktu lalu. Dan sebagian besar responden memilih berpegian keluar daerah yaitu ke
Manado sebanyak 58,1\%.

Tabel 13. Distribusi responden berdasarkan kunjungan tamu dan dari mana kunjungan tamu

\begin{tabular}{|c|c|c|}
\hline $\begin{array}{l}\text { Sering di kunjungi } \\
\text { keluarga (tamu) dan } \\
\text { menginap dirumah }\end{array}$ & Jumlah & $\begin{array}{c}\text { Persen } \\
(\%)\end{array}$ \\
\hline a. Ya & 45 & 23,2 \\
\hline b. Tidak & 149 & 76,8 \\
\hline Jumlah & 194 & 100 \\
\hline \multicolumn{3}{|l|}{$\begin{array}{l}\text { Dari mana kunjungan } \\
\text { tamu tersebut }\end{array}$} \\
\hline $\begin{array}{ll}\text { a. } & \text { Dari dalam } \\
& \text { Kab. Minahasa } \\
\text { Tenggara }\end{array}$ & 3 & 6,7 \\
\hline $\begin{array}{l}\text { b. Dari luar Kab. } \\
\text { Minahasa } \\
\text { Tenggara }\end{array}$ & 42 & 93,3 \\
\hline Jumlah & 45 & 100 \\
\hline
\end{tabular}

Tabel 14. Distribusi responden berdasarkan berpergian keluar daerah dan kemana tempat tujuan

\begin{tabular}{|c|c|c|}
\hline $\begin{array}{l}\text { Pernah berpergian keluar } \\
\text { daerah pada beberapa } \\
\text { waktu lalu }\end{array}$ & Jumlah & $\begin{array}{c}\text { Persen } \\
(\%)\end{array}$ \\
\hline a. $\mathrm{Ya}$ & 43 & 22,2 \\
\hline b. Tidak & 151 & 77,8 \\
\hline Jumlah & 194 & 100 \\
\hline \multicolumn{3}{|l|}{ Kemana pergi } \\
\hline a. Manado & 25 & 58,1 \\
\hline b. Langowan & 2 & 9,2 \\
\hline c. Tanawangko & 1 & 4,7 \\
\hline d. Kalimantan & 1 & 4,7 \\
\hline e. Irian J aya & 2 & 4,7 \\
\hline $\begin{array}{l}\text { f. Sangihe dan } \\
\text { Talaut }\end{array}$ & 1 & 2,3 \\
\hline g. Tenga & 4 & 2,3 \\
\hline h. Motoling & 1 & 2,3 \\
\hline i. Toil-toli & 1 & 2,3 \\
\hline j. $\quad$ Sonder & 2 & 2,3 \\
\hline k. Bali & 1 & 2,3 \\
\hline l. Amurang & 1 & 2,3 \\
\hline m. Singapur & 1 & 2,3 \\
\hline Jumlah & 43 & 100 \\
\hline
\end{tabular}

Berdasarkan Tabel 15, 83,7\% memilih ya dan 16,3\% memilih tidak dalam bermalam saat berpergian keluar daerah. 
Tabel 15. Distribusi responden berdasarkan bermalam saat berpegian keluar daerah

\begin{tabular}{ccc}
\hline $\begin{array}{l}\text { Bermalam saat } \\
\text { berpergian keluar } \\
\text { daerah }\end{array}$ & Jumlah & $\begin{array}{c}\text { Persen } \\
\text { (\%) }\end{array}$ \\
\hline a. Ya & 36 & 83,7 \\
b. Tidak & 7 & 16,3 \\
\hline Jumlah & 43 & 100 \\
\hline
\end{tabular}

BAHASAN

\section{Karakteristik Responden}

Umur responden yang diambil adalah15 tahun keatas karena merupakan usia dimana bisa menjawab pertanyaan yang ada dalam kuesioner dan sudah dapat mengerti maksud dari pertanyaan. Dari hasil penelitian yang telah dilakukan, sebagian besar responden berada pada golongan umur 40-50 tahun yaitu 27,8\% sedangkan kelompok umur yang paling sedikit ada pada golongan 15-20 tahun yaitu hanya $3,1 \%$.

Berdasarkan penelitian yang telah dilakukan untuk jenis kelamin sebagian besar responden adalah perempuan yaitu 62,4\% sedangkan laki-laki hanya 37,6\%. Saat pengambilan data pada siang sampai sore hari kebanyakan yang berada di rumah adalah perempuan, sedangkan laki-laki banyak yang pergi bekerja.

Dari jenis pekerjaan sebagian besar ibu rumah tangga yaitu sebanyak 51,5\%, sesuai dengan banyaknya jenis kelamin perempuan dalam responden. Kemudian ke dua terbanyak adalah petani yaitu $37,1 \%$, masyarakat yang bekerja sebagai petani yang lokasi pekerjaannya di kebun yang dekat dengan sungai, rawa dan sawah yang merupakan tempat perindukan nyamuk Anopheles spp. ${ }^{11}$ Hasil penelitian oleh Balai Penelitian Vektor Dan Reservoar Penyakit (BPVRP) menunjukan hasil bahwa pekerjaan yang berkaitan dengan pertanian mempunyai faktor risiko untuk menderita penyakit malaria sebesar 4,1 lebih besar daripada yang bekerja selain dibidang pertanian.

Dilihat dari tingkat pendidikan, paling banyak tamat SMP yaitu 50,5\% dan paling sedikit tamat perguruan tinggi yaitu
6,2\%. Sesuai penelitian yang pernah dilakukan ternyata tingkat pendidikan seseorang berpengaruh terhadap kebiasaankebiasaan buruk terhadap lingkungan seperti tidak pernah membersihkan lingkungan sendiri. Dimana kondisi lingkungan yang kotor merupakan faktor resiko penyakit malaria. ${ }^{8}$

\section{Tindakan Masyarakat Terhadap Penyakit Malaria}

Dari hasil wawancara menggunakan kuesioner pada 194 responden. Sebagian besar menyatakan bahwa pada malam hari sering melakukan aktivitas diluar rumah. Nyamuk Anopheles spp betina menggigit antara waktu senja sampai subuh dengan kepadatan yang berbeda-beda menurut spesiesnya. Responden mempunyai risiko cukup tinggi untuk digigit nyamuk Anopheles spp. Hal tersebut hampir sama dengan survey perilaku kesehatan masyarakat kaitannya dengan kejadian malaria di wilayah Puskesmas Kasimbar Kabupaten Parigi Sulawesi Tengah dan penelitian di Desa Tombatu 1 Kecamatan Tombatu Kabupaten Minahasa Tenggara. ${ }^{10}$

Aktivitas responden dimana sudah tidak berada di luar rumah (tidur) sebagian besar yaitu memilih pada jam 8 malam. Kebiasaan untuk berada di luar rumah sampai larut malam dapat meningkatkan faktor risiko malaria jika vektonya besifat eksofilik dan eksofagik. ${ }^{11}$ Kebiasaan tidur dari responden sebagian besar di kamar sedangkan untuk di ruang tamu dan di teras rumah tidak ada. Hal di atas mengurangi risiko dari vektor yang besifat eksofilik dan eksofagik bagi yang tidur di dalam rumah. ${ }^{8}$

Tindakan dalam mengurangi atau menghindari kontak atau gigitan nyamuk Anopheles spp yaitu kepemilikan kelambu, kebiasaan menggantung pakaian didalam rumah, menggunakan obat pembasmi nyamuk setiap malam, menggunakan repelen pada malam hari serta menggunakan kawat kasa pada ventilasi merupakan tindakan yang penting dalam menyehatkan lingkungan yang berhubungan dengan penyakit malaria. Untuk kepemilikan kelambu sebagian besar 
responden memiliki kelambu. Penggunaan kelambu saat tidur pada malam hari sangat penting karena nyamuk Anopheles spp betina menggigit antara waktu senja sampai subuh. Hasil penelitian ini sama dengan penelitian di Kabupaten Kepulauan Mentawai Provinsi Sumatera Barat tahun 2011, dimana didapat sebagian besar responden memiliki kelambu. ${ }^{1}$ Hasil penelitian pada tahun 2011 di Desa Talawaan didapat sebagian besar masyarakat tidak menggunakan kelambu pada malam hari. ${ }^{12}$ Penggunaan kelambu pada waktu tidur malam hari merupakan salah satu cara efektif untuk menghindari gigitan nyamuk, khususnya kelambu yang dilapisi insektisida.

Kebiasaan menggantung pakaian didalam rumah sebagian besar responden menjawab ya, walaupun mereka sudah mengetahui jika menggantung pakaian di dalam ruangan merupakan tempat yang disenangi nyamuk untuk beristirahat dan pada saatnya akan menghisap darah manusia kembali, sehingga menggantung pakaian di dalam rumah merupakan faktor risiko penyakit malaria. Hasil penelitian ini sama dengan penelitian pada tahun 2010 di Desa Koka Kecamatan Tombulu Kabupaten Minahasa, dimana sebagian besar dari responden memiliki kebiasaan menggantung pakaian di dalam rumah. ${ }^{13}$

Tindakan menggunakan obat pembasmi nyamuk sebagian besar menjawab hanya kadang-kadang menggunakan obat pembasmi nyamuk pada malam hari. Responden yang tidak menggunakan obat pembasmi nyamuk berpendapat walaupun sudah memakai obat pembasmi nyamuk tetap masih banyak nyamuk. Untuk data penelitian tentang penggunaan obat pembasmi nyamuk yang ada pada judul skripsi perilaku masyarakat tentang penyakit malarian di desa Tombatu $1,{ }^{10}$ dan penelitian di Kabupaten Kepulauan Mentawali Provinsi Sumatera Barat tahun 2011 didapat sebagian besar responden sudah menggunakan obat nyamuk untuk menghindari gigitan nyamuk Anopheles spp. ${ }^{1}$

Penggunakan repelen sebagian besar menjawab tidak menggunakan pada malam hari. Responden yang sebagian besar tidak menggunakan repelen pada malam hari kurang mengetahui manfaat dari repelen sendri sehingga mereka hanya mengangap obat pembasmi nyamuk saja sudah cukup. Hasil penelitian tersebut sama dengan penelitian pada tahun 2010 di Desa Tombatu 1 Kecamatan Tombatu. ${ }^{10}$

Kawat kasa pada ventilasi sebagian besar responden tidak menggunakan hanya beberapa responden yang menggunakan. Masyarakat yang tinggal didaerah endemis malaria seperti pada kecamatan Silian Raya ini sebaiknya menggunakan kawat kasa pada ventilasi untuk mencegah nyamuk Anopheles spp masuk. Menurut penelitian di Kecamatan Rajabasa Kabupaten Lampung Selatan memakai kawat kasa pada ventilasi rumah akan menurunkan resiko terjadinya penyakit malaria. ${ }^{12}$ Tapi sebagian besar masyarakat tidak menggunakan kawat kasa pada ventilasi, masyarakat hanya menganggap hal itu tidak penting dan kurang berguna dalam mencegah nyamuk anopheles masuk. Penelitian ini hampir sana dengan penelitian pada tahun 2011 di Desa Talawaan karena berdasarkan penelitian tersebut semua responden tidak menggunakan kawat kasa pada ventilasi rumah. Hal ini tidak jauh beda dengan penelitian di Kabupaten Kepulauan Mentawai Provinsi Sumatera Barat tahun 2011 dimana hanya sebagian kecil responden yang menggunakan kawat kasa pada ventilasi rumah. ${ }^{1,13}$

Berdasarkan data kunjungan keluarga atau tamu dan menginap di rumah didapat paling banyak dari di luar Kabupaten Minahasa Tenggara. Dari hasil wawancara yang didapat paling banyak dari Manado dan daerah-daerah lain di provinsi Sulawesi Utara yang bukan daerah endemis malaria. Sejak dulu diketahui penyakit malaria ini sering terjadi pada pendatangpendatang di daerah endemis malaria yang dari daerah lain yang belum mempunyai kekebalan sehingga rentan terinfeksi. Meningkatnya perjalanan ke daerah endemis mengakibatkan kasus impor. ${ }^{10}$ 
Tindakan responden dalam berpergian ke luar daerah didapat 22,2\% pernah berpergian keluar daerah, dan kemana responden pergi didapat sebagian besar ke Manado. Dan untuk yang bermalam saat berpergian ditemukan 83,7\% bermalam saat berpergian keluar daerah. Perjalanan dari daerah endemis malaria ke daerah lain dapat memungkinkan terjadinya penularan penyakit malaria. Daerah yang penduduknya tidak mempunyai kekebalan terhadap penyakit akan tertular penyakit yang dibawah para pendatang. Sedangkan untuk lamanya tinggal saat berkujung tidak terbukti berhubungan dengan kejadian malaria, sesuai dengan penelitian yang dilakukan di kecamatan Lengkong Kabupaten Sukabumi. ${ }^{11}$

\section{SIMPULAN}

Berdasarkan hasil penelitian yang telah dilakukan maka dapat disimpulkan tindakan masyarakat terhadap penyakit malaria di Kecamatan Silian Raya Kabupaten Minahassa Tenggara ditemukan antara lain kebiasaan berada diluar rumah pada malam hari sebesar 90,2\%, kebiasaan menggantung pakaian didalam rumah sebesar 93,3\%, kebiasaan dalam menggunakan obat nyamuk yang hanya 24,7\%, kebiasaan dalam penggunaan repelen atau autan sebesar $1,5 \%$, dan penggunaan kawat kasa ventilasi sebesar $4,6 \%$.

\section{DAFTAR PUSTAKA}

1. Media $Y$, Tinabasilih, Sefyan $S$. Pengetahuan, Sikap dan Perilaku Kaitannya dengan Penularan dan Pencegahan Malaria di Kabupaten Kepulauan Mentawali Provinsi Sumatera Barat. Jurnal Ekologi Kesehatan. 2011; 10:187-94

2. Ma'ruf A. Gambaran Perilaku Masyarakat tentang Penyakit Malaria di Desa Tunggulo Kecamatan Limboto Barat Kabupaten Gorontalo[skripsi]. [Gorontalo]: Universitas Negeri Gorontalo;

3. Santy, Fitriangga A, Natalia D. Hubungan Faktor Individu dan Lingkungan dengan Kejadian Malaria di Desa Sungai Ayak 3
Kecamatan Belitang Hilir Kabupaten Sekadu. Jurnal Hubungan Faktor Individu dengan Malaria. 2014; 2:265-72

4. Gusra T, Irawati N, Sulastri D. Gambaran Penyakit Malaria di Puskesmas Terusan dan Puskesmas Balai Selasa Kabupaten Pesisir Selatan Periode Januari-Maret 2013. Jurnal Kesehatan Andalas. 2014; 3:234-7

5. Asa PE, Umboh JML, Pangemanan J. Pengaruh Penggunaan Kelambu, Repellent, Bahan Anti Nyamuk dan Kebiasaan Keluar Rumah Malam Hari Terhadap Kejadian Malaria Di Desa Lobu dan Lobu II Kecamatan Toluaan Kabupaten Minahasa Tenggara. [jurnal]. [Manado]: Universitas Sam Ratulangi; 2013

6. Laporan Bulanan Kasus Malaria Puskesman Silian Raya. Januari-Oktober 2014

7. Profil Kecamatan Silian Raya. 2014

8. Saragih N. Gambaran Perilaku Masyarakat Tentang Penyakit Malaria Di Desa Bagian Asahan Kecamatan Tanjung Balai Kabupaten Asahan. [skripsi]. [Medan]: Universitas Sumatera Utara; 2004

9. Dewi, G. Faktor-Faktor Yang Berhubungan Dengan Tindakan Masyarakat Terhadap Penderita Kusta Di Jorong Kumang Kanagarian Panti Kecamatan Panti Kabupaten Pasman Tahun 2008. [penelitian keperawatan komunitas]. [Padang]: Universitas Andalas; 2011

10. Tingginehe S. Perilaku Masyarakat Terhadap Pencegahan Penyakit Malaria Di Desa Tombatu 1 Kecamatan Tombatu Kabupaten Minahasa Tenggara[skripsi]. [Manado]: Universitas Sam Ratulangi; 2010

11.Marliah SHR. Faktor-Faktor yang Berhubungan dengan Kejadian Malaria Pada Penduduk Kecamatan Lengkong Kabupaten Sukabumi yang Pernah Bermigrasi Tahun 2011. [skripsi]. [Depok]: Universitas Indonesia; 2012

12.Korompis AC. Tindakan Masyarakat Terhadap Penyakit Malaria Di Desa Talawaan Kecamatan Wori Kabupaten Minahasa Utara [skripsi]. [Manado]: Universitas Sam Ratulangi; 2011

13.Lesar T. Gambaran Perilaku Masyarakat Terhadap Penyakit Malaria Di Desa Koka Kecamatan Tombulu Kabupaten Minahasa [skripsi]. Manado: Universitas Sam Ratulangi, 2010 